\title{
STRUCTURE OF THE INCOMPATIBILITY GENE
}

\section{INDUCED MUTATION RATE}

By D. LEWIS

John Innes Horticultural Institution, Bayfordbury, Hertford, Herts.

\section{CONTENTS}

Received r r.iv.49

I. Introduction . . . . . . . . . . . 339

2. Material and Methods . . . . . . . . . . . 340

3. Results . . . . . . . . . . . . 341

(a) Effect of Dosage . . . . . . . . . . . . . . . 341

(b) Temperature During Irradiation . . . . . . . . 342

(c) Sensitivity and the Nuclear Cycle . . . . . . 344

(d) The Mutation Constant . . . . . . . . . . 347

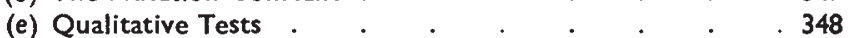

(f) Crossing-over within the S gene . . . . . . . . 351

4. Discussion . . . . . . . . . . . 352

(a) Nature of $\mathbf{S}$ gene mutants : Temperature Effect . . . 352

(b) Divisibility of the Gene . . . . . . . . . . 353

5. Summary . . . . . . . . . . . . . . . 354

6. References . . . . . . . . . . . . . . . 354

\section{INTRODUCTION}

INcompatibILITY genes have been shown to be very suitable for the study of mutations particularly in Oenothera organensis and Prunus avium (Lewis, 1948). The first object of the work was to test methods for detecting mutants and to find the spontaneous rate in different clones which would be used in X-ray experiments.

The special advantages of the $\mathbf{S}$ gene for spontaneous mutation studies have been described previously, and as these apply equally to $\mathrm{X}$-ray work they will not be reiterated.

Some of the results with X-rays reported in this article have been known in other organisms for some time; this repetition has been necessary, however, in order to find if the new material and methods give a picture of $\mathrm{X}$-ray induced mutation which is consistent with the known data obtained by other methods. Furthermore, as much of the published work on induced mutations has been on lethal genes in Drosophila, the publication of similar results with a non-lethal gene and in plants appears to be justified.

In addition some results are new; these have been revealed only by the special properties of the $\mathbf{S}$ gene-properties that facilitate the selection and fine analysis of mutants but that do not distinguish this gene fundamentally from others. Thus it is possible from data obtained with this gene to draw general conclusions. 


\section{MATERIAL AND METHODS}

Mutants were detected by two methods, pollen-tube count and seed production, following those already described (loc. cit.). The irradiation was given unfiltered at $75 \mathrm{kV}$ and $6 \mathrm{~mA}$ with $300 \mathrm{~mm}$. average target distance using a field $150 \mathrm{~mm}$. in diameter, that is, at a mean measured intensity over the field of $\mathrm{I}$ I 0 roentgen units per minute.

With few exceptions temperature was controlled during irradiation to within $\mathrm{I}^{\circ} \mathrm{C}$. and the material was kept in this temperature for $3^{\circ}$ minutes before and 60 minutes after the treatment. Temperature was not otherwise controlled.

The plants treated were Otnothera organensis and the sweet cherry, Prunus avium. The clones of Oenothera and the clonal varieties of Prunus and their incompatibility groups after Crane and Brown (I937) are given below :-

Oenothera organensis

\begin{tabular}{|l|ll|ll|}
\hline $\left.\begin{array}{l}\mathbf{1}^{14} \\
\mathbf{I}^{18}\end{array}\right\} \mathbf{S}_{3} .6$ & $2^{12}$ & $\mathbf{S}_{4} .6$ & $\mathbf{I}^{2}$ & $\mathbf{S}_{2.6}$ \\
\hline
\end{tabular}

Prunus avium

\begin{tabular}{|l|c|c|}
\hline Group III, $\mathbf{S}_{3.5}$ & Group V, S & Group VII, $\mathbf{S}_{4.5}$ \\
\hline $\begin{array}{l}\text { Bigarreau Napoléon } \\
\text { Emperor Francis } \\
\text { Mezel 2 }\end{array}$ & $\begin{array}{l}\text { Bohemian Black } \\
\text { Late Black Bigarreau } \\
\text { Ohio Beauty }\end{array}$ & $\begin{array}{l}\text { Bradbourne Black } \\
\text { Géante de Hedelfingen } \\
\text { Hooker's Black }\end{array}$ \\
& $\ldots$ & $\ldots$ \\
\hline
\end{tabular}

In most of the experiments irradiation was given to the flower buds when the pollen mother cells were in meiosis, but buds in earlier and later stages of development and mature pollen were also treated. To determine the stage of development at the time of treatment samples were taken and examined by the aceto-carmine and lacmoid squash methods. The two species differed in the mode of their bud development and thus each required a different experimental procedure. The pollen mother cells in Prunus all develop more or less at the same time, thus all the buds on a branch at any one time are, within certain limits, at the same stage of development. These limits were not easy to determine accurately ; pollen mother cells in first and second division could be found in the same sample and second-division stages with tetrads, but it was rare to find pollen mother cells as widely different as metaphase I and tetrads. Thus to compare the effect of treatments at different stages of development several treatments have to be given to different branches over a period of time.

On a single shoot of Oenothera there are buds, at any one time, in every stage from minute primordia to open flowers. These are arranged in a regular order on the flowering shoots, one in each leaf axil with the open flower at the base and successively younger 
buds towards the top of the shoot. A bud approximately $6 \mathrm{~mm}$. in length, that is, one which is the seventh or eighth above an open flower, is either in, or very near to, the first division of meiosis. Thus to treat buds at different stages of development only one treatment is necessary.

The procedure was to mark buds that were $6 \mathrm{~mm}$. long at the time of irradiation and to use the pollen from the flowers that open each day for 30-40 days after irradiation. The marked buds open into flowers I3-2 I days after irradiation according to the temperature conditions. Hence, although the time scale may vary from one experiment to another, the marked buds are strictly comparable and serve as a dividing line to which all other buds can be referred.

\section{Calculation of mutation rates}

In all calculations of the number of mutations due to treatment the spontaneous rate has been deducted. The calculation of the number of treated $\mathbf{S}$ genes tested for mutation is obtained from the formula :-

$$
\frac{\mathrm{N} k}{2^{n}}
$$

Where $\mathrm{N}=$ the number of flowers pollinated

$k=$ the number of pollen grains on a stigma

$n=$ the number of gene reproductions between the stage treated and the gene reproduction immediately preceding pollen grain mitosis.

\section{RESULTS}

(a) Effect of dosage

No large scale experiment was made to establish the relationship between mutation and the X-ray dose, but tests to find the best dose for other experiments gave some data, which, although meagre, at least do not conflict with the direct relationship that has been found in other gene mutation studies. Tests made in Prunus, group V, $\mathbf{S}_{3.4}$, are summarised in table $I$ and fig. $I$.

TABLE 1

Fruit set from $X$-ray doses given at early prophase after incompatible pollination in Prunus group $V$

\begin{tabular}{|c|c|c|c|c|}
\hline Dose $r$ units & Temperature & Flowers pollinated & Fruits set & $\begin{array}{l}\text { Fruits per soo flowers } \\
\text { due to treatment * }\end{array}$ \\
\hline $\begin{array}{r}90 \\
200 \\
300 \\
450 \\
600 \\
800\end{array}$ & $\begin{array}{l}15^{\circ} \\
15^{\circ} \\
15^{\circ} \\
15^{\circ} \\
18^{\circ} \\
18^{\circ}\end{array}$ & $\begin{array}{r}351 \\
405 \\
948 \\
1181 \\
742 \\
885\end{array}$ & $\begin{array}{r}1 \\
4 \\
8 \\
16 \\
21 \\
21\end{array}$ & $\begin{array}{l}0.03 \\
0.63 \\
0.59 \\
1.09 \\
2.60 \\
2.12\end{array}$ \\
\hline
\end{tabular}

* In this column a value of 0.25 , which is the fruit set due to spontaneous mutation has been subtracted. 
(b) Temperature during irradiation

Although Timoféeff Ressovsky and Zimmer (1939) with sex-linked lethals and Muller (1940) with sex-linked lethals and II and III chromosome translocations in Drosophila and Stadler (1930) with dormant and germinating barley seeds found no effect of temperature

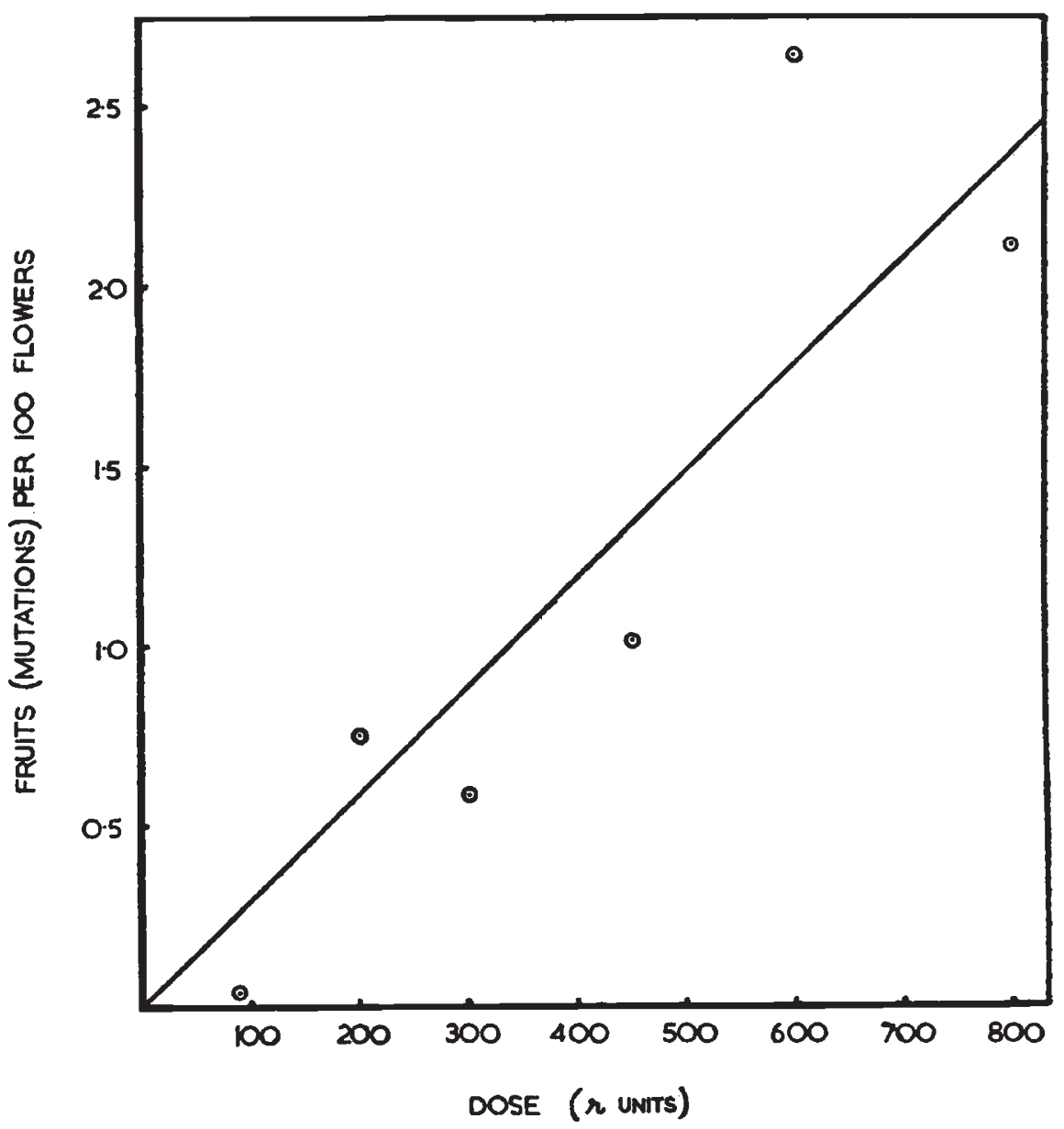

FIG. 1.-Relationship between mutation frequency and X-ray dose in Prunus avium.

during irradiation it was thought necessary to check this for three reasons :-(I) The very different states of the nuclei in the materials used-pollen mother cells of Prunus and Oenothera as compared with ripe sperm of Drosophila or with somatic tissue of barley seeds. (2) The difference in the selective sieves through which the mutants have to pass-S gene mutations induced in pollen mother cells must be viable in the haploid gametophyte, while recessive lethals in Drosophila and mutants in barley seeds are subjected to a less rigorous selection 
which allows gross chromosomal changes to pass. (3) The positive effect of temperature on chromatid reunion and sister reunion in Tradescantia pollen grains (Darlington and La Cour, I945).

The results in Prunus show that temperature has an effect both on the percentage of fruits set and on seeds produced when the irradiation is given in the early prophase of meiosis (table 2). This effect is highly significant in group VII cherries and, although in group III the results are not significant the difference is in the same direction.

TABLE 2

Effect of temperature during and I hour after irradiation in Prunus avium; results above and tests of significance below. Dose, $600 \mathrm{r}$.

\begin{tabular}{|c|c|c|c|c|c|c|}
\hline Group & Genotype & $\begin{array}{c}\text { Temperature } \\
{ }^{\circ} \mathrm{C} \text {. }\end{array}$ & $\begin{array}{l}\text { Stage at } \\
\text { irradiation }\end{array}$ & Flowers & $\begin{array}{l}\text { Fruit set } \\
\text { per cent. }\end{array}$ & $\begin{array}{c}\text { Seeds } \\
\text { per cent. }\end{array}$ \\
\hline $\begin{array}{l}\text { III } \\
, " \\
", \\
\text { VIII } \\
",\end{array}$ & $\begin{array}{l}\mathbf{S}_{3.5} \\
\mathbf{S}_{3.5} \\
\mathbf{S}_{3.5} \\
\mathbf{S}_{3.5} \\
\mathbf{S}_{4.5} \\
\mathbf{S}_{4.5}\end{array}$ & $\begin{array}{r}9 \\
24 \\
10 \\
24 \\
10 \\
24\end{array}$ & $\begin{array}{l}\text { Early prophase } \\
\text { ", ,' } \\
\text { Metaphase } \\
\text { Early prophase } \\
\text { ", ", }\end{array}$ & $\begin{array}{r}1732 \\
960 \\
2151 \\
1995 \\
1619 \\
145^{2}\end{array}$ & $\begin{array}{l}0 \cdot 4 \\
0 \cdot 6 \\
r \cdot 5 \\
r \cdot 6 \\
r \cdot 0 \\
2 \cdot I\end{array}$ & $\begin{array}{l}0 \cdot 18 \\
0.48 \\
0 \cdot 97 \\
0.80 \\
0.32 \\
0.83\end{array}$ \\
\hline
\end{tabular}

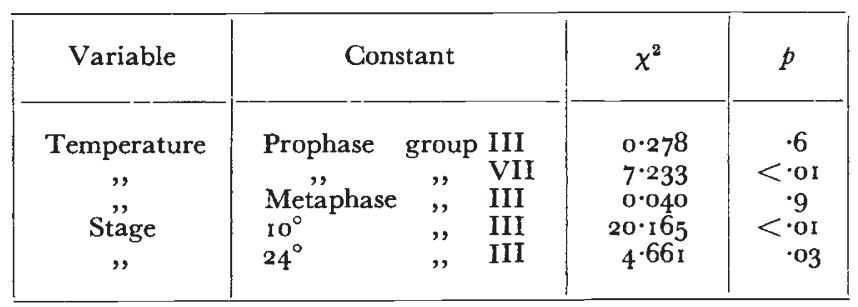

Controls using a high temperature without X-radiation, were provided from an experiment designed to detect any effect of temperature on spontaneous mutation. Group III trees of Prunus were kept at $27^{\circ} \mathrm{C}$. for three different periods :-(I) 4 days from the resting stage to metaphase of meiosis, (2) i 3 hours from zygotene to the end of pachytene and (3) I 3 hours from diakenesis to metaphase. No effect of these treatments on the spontaneous mutation rate could be found; the combined data are given below :-

$$
\begin{array}{rrrccc} 
& & \text { Flowers } & \text { Fruit set } \\
\text { Treatments, I, } 2 \text { and } 327^{\circ} \mathrm{C} . & . & . & 3054 & 0.16 \text { per cent. } \\
12-13^{\circ} \mathrm{C} . & . & . & 6428 & 0.13 \quad "
\end{array}
$$

For a fifteen degree rise in temperature the mutation rate of the $\mathbf{S}$ gene under $\mathrm{X}$-radiation is approximately doubled.

In both groups the effect appears to be greater when measured as "seed set" than as "fruit set" and this is probably an important difference because the seeds represent only mutations of the $\mathbf{S}$ gene that are fully viable in the male gametophyte and are not lethal in 
the embryo, while the fruits include mutations that are dominant lethals in the embryo as well.

During irradiation given at a stage which is estimated by examination to be metaphase I-or at least with certainty when the chromosomes are spiralised and condensed-temperature has no effect.

Results of a temperature test in Oenothera show an effect similar to that in Prunus, table 3 ; again a rise of $14^{\circ} \mathrm{C}$. during irradiation produces a doubling of the mutation rate. It was not possible with these data in Oenothera to distinguish sharply between mutations occurring under different states of the chromosomes, as the treatments had to be given to buds in every condition and the total number tested was not large enough to be able to separate the mutants in respect to the stage of treatment.

TABLE 3

Effect of temperature during and $I$ hour after irradiation in Oenothera organensis. Dose $1000 \mathrm{r}$.

\begin{tabular}{|c|c|c|c|c|c|c|}
\hline Clone & Genotype & Temperature & Flowers & $\begin{array}{l}\text { Pollen tubes per } \\
\text { Ioo flowers }\end{array}$ & $x^{2}$ & $p$ \\
\hline $\begin{array}{l}I^{2} \\
I^{18}\end{array}$ & $\begin{array}{l}\mathbf{S}_{2.6} \\
\mathbf{S}_{2.6} \\
\mathbf{S}_{3.6} \\
\mathbf{S}_{3.6}\end{array}$ & $\begin{array}{l}18 \\
32 \\
18 \\
32\end{array}$ & $\begin{array}{c}74 \\
108 \\
121 \\
35\end{array}$ & $\begin{array}{r}4.1 \\
7 \cdot 9 \\
6 \cdot 9 \\
15 \cdot 8\end{array}$ & $\begin{array}{l}x \cdot 216 \\
2 \cdot 406\end{array}$ & $\begin{array}{l}\cdot 2 \\
\cdot 1\end{array}$ \\
\hline
\end{tabular}

With the high dose employed in this experiment, buds irradiated late in meiosis tend to fall-off prematurely, and therefore mutants induced during this stage are underestimated in the sample. Thus the majority of mutants in these samples represent changes occurring early in prophase of meiosis.

The Oenothera results are not significant in themselves but taken with the Prunus results there is overwhelming evidence for the temperature effect.

\section{(c) Sensitivity and the nuclear cycle}

The data on Prunus avium given in table 2-assembled primarily to show the effect of temperature-hint at a different sensitivity to $\mathrm{X}$-rays between prophase and metaphase of meiosis.

Thus at $9-10^{\circ} \mathrm{C}$. the percentage of fruit set with irradiation at metaphase is more than three times that from comparable prophase treatments ; the same comparison based on seed set shows more than a fourfold difference. At $24^{\circ}$ these differences are smaller, nevertheless at both temperatures the differences are significant as shown by the $\chi^{2}$ in table 2 .

On the most acceptable view of the meiotic chromosomes that chromosome division occurs at pachytene, and on the assumption that the gene reproduces at about the same stage, much of the apparent difference in sensitivity to X-rays is accounted for. To make a 
comparison of sensitivity we must, therefore, apply a correction factor of 2, either by multiplying the number of "prophase" mutants, or dividing the number of "metaphase" mutants, by two. Values corrected by halving the number of metaphase mutants give a $\chi^{2}$ of I. $55^{8}(p=\cdot 2)$ at $9^{\circ}$ and $0 \cdot 165(p=\cdot 6)$ at $24^{\circ}$. Thus the difference at $24^{\circ}$ has largely disappeared, while at $9^{\circ}$, although the difference is not now significant, it suggests a real effect.

\section{TABLE 4}

Mutations produced by $600 \mathrm{r}$ units at $20^{\circ} \mathrm{C}$. given to buds of Oenothera organensis $\mathrm{x}^{14}$, $\mathrm{S}_{3} .6$ showing the relationship between stage of treatment and the number of mutants

\begin{tabular}{|c|c|c|c|c|c|}
\hline & & $\begin{array}{l}\text { Days after } \\
\text { irradiation }\end{array}$ & $\begin{array}{l}\text { Number of } \\
\text { flowers }\end{array}$ & $\begin{array}{l}\text { Compatible pollen-tubes } \\
\text { (mutations) }\end{array}$ & $\begin{array}{l}\text { Induced mutations } \\
\text { per } 10^{\circ} \mathrm{S} \text { genes * }\end{array}$ \\
\hline 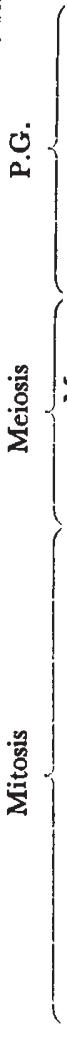 & | & $\begin{array}{r}3 \\
4 \\
5 \\
6 \\
7 \\
8 \\
9 \\
10 \\
11 \\
12 \\
13 \\
14 \\
15 \\
16 \\
17 \\
18 \\
19 \\
20 \\
21 \\
22 \\
23 \\
24 \\
25 \\
26 \\
27 \\
28 \\
29 \\
30 \\
31 \\
32 \\
33 \\
34 \\
35 \\
36 \\
37 \\
38 \\
39\end{array}$ & $\begin{array}{r}19 \\
8 \\
9 \\
12 \\
8 \\
36 \\
26 \\
23 \\
38 \\
44 \\
34 \\
44 \\
31 \\
97 \\
60 \\
60 \\
105 \\
76 \\
94 \\
94 \\
35 \\
20 \\
46 \\
44 \\
71 \\
18 \\
60 \\
42 \\
47 \\
36 \\
54 \\
37 \\
79 \\
24 \\
23 \\
16 \\
46\end{array}$ & 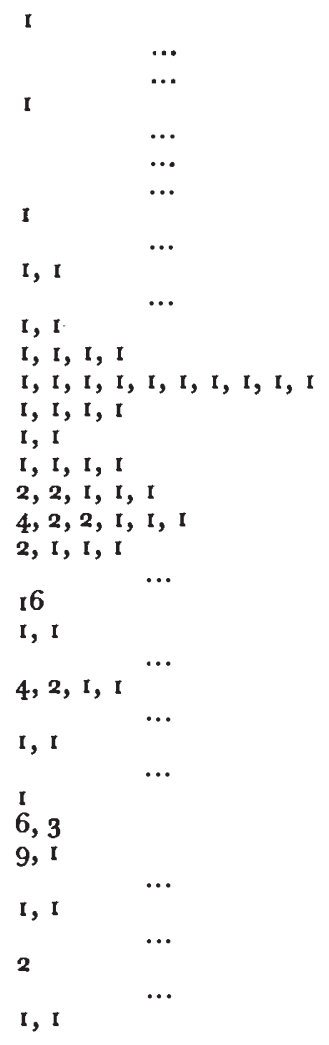 & $\begin{array}{r}17 \cdot 8 \\
5 \cdot 5 \\
21 \cdot 0\end{array}$ \\
\hline
\end{tabular}

* Spontaneous mutations ( $1 \cdot 7$ per $10^{7} \mathrm{~S}$ genes) have been deducted. It is not possible to calculate the mutation rate based on the number of genes irradiated later than the 22nd day after treatment, because the mitotic divisions occur in rapid succession thus making it impossible to estimate the number of genes treated.

Further evidence on this point comes from Oenothera. The data given in table 4 are the combined results of two irradiations, one given in 1946 , and the other in 1947 . The distribution of the mutants 
with time after irradiation, and therefore, with the stage of development at irradiation, was very similar in the two treatments; thus they have been combined for ease of presentation.

There are three points emerging from this experiment :-

(i) The great increase in the percentage of styles found with a single compatible (mutant) pollen tube from pollen irradiated late in meiosis.

(ii) The appearance of two or more compatible pollen tubes in a single style from pollen irradiated 5 days before metaphase of meiosis. This is followed within 24 hours by groups of four compatible pollen tubes.

(iii) A tendency to a low percentage of mutants occurring after the high number at metaphase and before the appearance of " double" mutants.

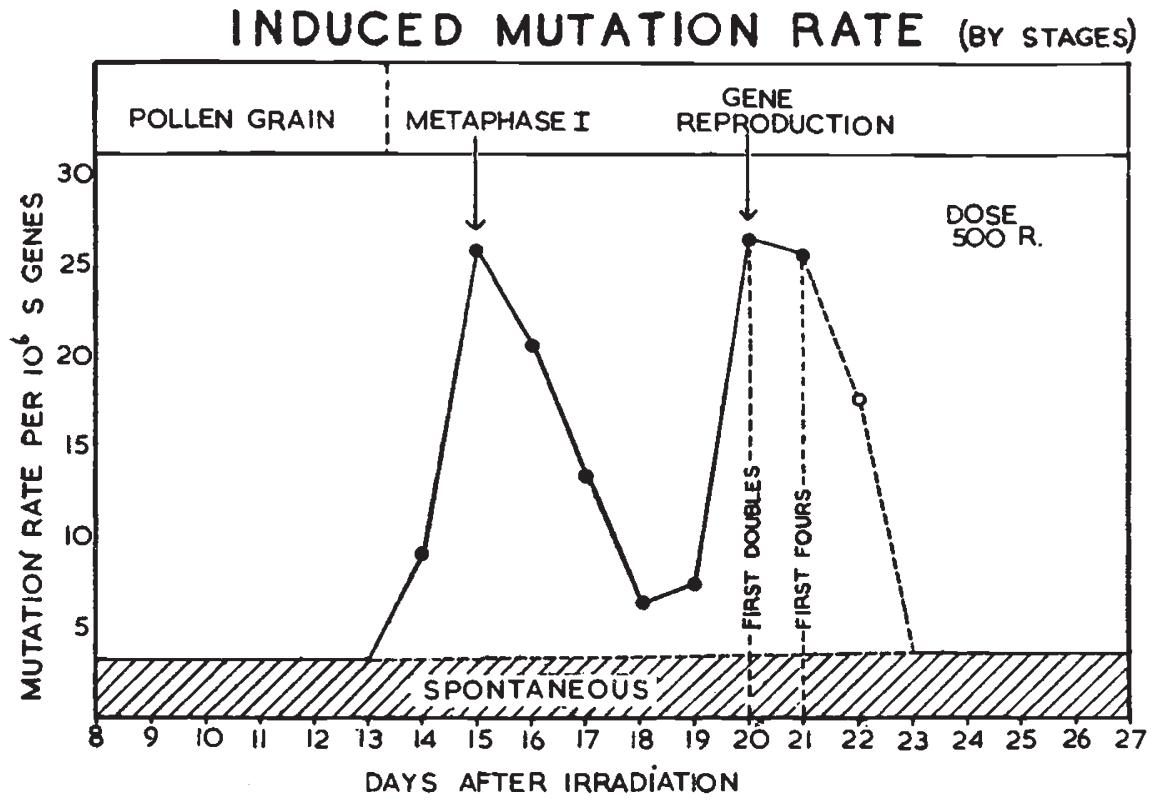

Fro. 2.-Relationship between nuclear stage irradiated and the sensitivity to $X$-rays as measured by the induced mutation of the $\mathbf{S}$ gene in Oenothera organensis by the compatible pollen tube method.

Double mutants are the result of irradiation before the $\mathbf{S}$ gene has divided. Therefore, to make a comparison of the sensitivity at different stages, the number of such mutants must be multiplied by two. This and a correction for the spontaneous rate has been made in fig. 2 which clearly shows a highly sensitive period when the chromosomes are condensed in late meiosis with metaphase $\mathrm{I}$ at the peak, preceded by a less sensitive stage, and again by a more sensitive stage when double mutants appear.

These results confirm those in Prunus and together they suggest that it is a general rule for gene sensitivity to X-rays to vary during 
the nuclear cycle. There are, however, certain aspects of the results in the two species that can only be reconciled by assuming that the gene divides from the point of view of X-ray mutability before pachytene. For, if the period of low sensitivity corresponds to the same stage of the nuclear cycle in the two species, this stage being the beginning of prophase in Prunus, then the absence of double mutants in Oenothera means that the gene has divided before this early stage.

Another and quite different aspect of the induction of mutants by X-rays at different stages of development is found in the mature pollen. Doses up to $4000 r$ have been given to mature Oenothera pollen without inducing mutations. This is due simply to the fact that the character, mating reaction of the pollen, has been laid down before this stage. In a similar way large doses given to mature pollen have no effect on germination (Poddubnaja-Arnoldi, I936; Newcombe, I942).

\section{(d) The mutation constant}

To be able to compare the effect of a comparable dose of X-rays in Prunus and Oenothera, the mutation constants (the probability $a$ that a gene should mutate for a dose of one roentgen unit) are given

TABLE 5

Mutation constants calculated for $I \mathrm{r}$ unit of $X$-radiation. ("Fruit," "Seed," and "Pollen tube" refer to the method of scoring. The rates calculated from seed set are lower than from fruit set owing to zygotic lethals.)

\begin{tabular}{|c|c|c|c|c|c|}
\hline \multirow{2}{*}{ Genotype } & \multirow{2}{*}{$\begin{array}{c}\text { Temperature } \\
{ }^{\circ} \mathrm{C} \text {. }\end{array}$} & \multirow{2}{*}{ Stage at irradiation } & \multicolumn{3}{|c|}{ Mutation constants $\times \mathbf{r O}^{-8}$} \\
\hline & & & Pollen tube & Fruits & Seed \\
\hline \multicolumn{6}{|c|}{ Prunus avium } \\
\hline $\begin{array}{l}\mathbf{S}_{3.5} \\
\mathbf{S}_{4 \cdot 5}\end{array}$ & $\begin{array}{r}9 \\
24 \\
10 \\
24 \\
10 \\
24\end{array}$ & $\begin{array}{l}\text { Early prophase } \\
\text {,',", } \\
\text { Metaphase" } \\
\text { Early prophase } \\
\text {,, ", }\end{array}$ & $\begin{array}{l}\cdots \\
\cdots \\
\cdots \\
\cdots \\
\cdots\end{array}$ & $\begin{array}{l}1 \cdot 4 \\
1 \cdot 9 \\
2 \cdot 3 \\
2 \cdot 4 \\
3 \cdot 0 \\
6 \cdot 8\end{array}$ & $\begin{array}{l}0 \cdot 7 \\
1 \cdot 4 \\
1 \cdot 5 \\
1 \cdot 3 \\
1 \cdot 1 \\
2 \cdot 7\end{array}$ \\
\hline \multicolumn{6}{|c|}{ Oenothera organensis } \\
\hline $\begin{array}{l}\mathbf{I}^{2} \mathbf{S}_{2.6} \\
\mathbf{I}^{18} \mathrm{~S}_{3} .6 \\
\mathbf{I}^{14} \mathrm{~S}_{3} .6\end{array}$ & $\begin{array}{l}18 \\
32 \\
18 \\
32 \\
20 \\
20\end{array}$ & $\begin{array}{l}\text { All stages * } \\
\text {," ," } \\
\text { ", ", } \\
\text { E’," prophase } \\
\text { Metaphase }\end{array}$ & $\begin{array}{l}1 \cdot 5 \\
3 \cdot 1 \\
2 \cdot 8 \\
6 \cdot 8 \\
1 \cdot 0 \\
2 \cdot 9\end{array}$ & $\begin{array}{l}\cdots \\
\cdots \\
\cdots \\
\cdots \\
\cdots \\
\cdots\end{array}$ & $\begin{array}{l}\cdots \\
\cdots \\
\cdots \\
\cdots \\
\cdots \\
\cdots\end{array}$ \\
\hline
\end{tabular}

* Calculated from the number of pollen grains and not from the number of treated $\mathbf{S}$ genes.

in table 5. The constants for the prophase treatments in Prunus have been derived from figures corrected by a factor of 2 based on the 
assumption that the gene had not reproduced at this stage. If, as was suggested previously the gene had reproduced before this, these constants are twice too large. By not applying this correction factor in Prunus, the comparison between metaphase and prophase sensitivities would agree even more closely in the two species.

It is clear from the table that the constants differ according to the clone, the stage of nuclear cycle and the temperature at irradiation, and the range of variation due to these causes is similar in the two species.

(e) Qualitative tests on mutants

Induced mutations of the incompatibility gene obtained as seeds in Prunus avium, have produced progeny but it will be several years before they flower and can be tested qualitatively. In the meantime similar mutants in Oenothera organensis have flowered and have been tested.

From 19 flowers of clone $I^{14}\left(S_{3} .6\right)$ that were pollinated in 1945 with pollen from anthers of clone $\mathrm{I}^{18}\left(\mathbf{S}_{3} .6\right)$, irradiated with $500 \mathrm{r}$ units, 37 days previously, one capsule was obtained which contained 36 seeds. Thirty-four plants, all of normal vigour, were produced and these were all fully self-compatible. The results of selfing tests on a selection of the plants is given in table 6. And from pollen-tube

\section{TABLE 6}

Results of self-pollination of self-compatible Oenothera plants, $\mathrm{S}_{3} .6^{\prime}$ and $\mathrm{S} 6.6^{\prime}$ from an $X$-ray mutation, compared with compatible pollination of normal plants

\begin{tabular}{|c|c|c|c|c|}
\hline & $\begin{array}{l}\text { Different } \\
\text { plants }\end{array}$ & Flowers & Capsules & $\begin{array}{l}\text { Mean seeds per } \\
\text { capsule }\end{array}$ \\
\hline $\begin{array}{l}\mathrm{S}_{3} \cdot 6^{\prime} \text { selfed } \\
\text { S6.6 selfed : } \\
\text { Normal crossed }\end{array}$ & $\begin{array}{r}9 \\
\text { I I } \\
4\end{array}$ & $\begin{array}{l}10 \\
12 \\
17\end{array}$ & $\begin{array}{l}10 \\
12 \\
17\end{array}$ & $\begin{array}{l}278 \\
264 \\
242\end{array}$ \\
\hline
\end{tabular}

growth studies and records of capsules set on all the plants after self-pollination no difference whatever could be found between their behaviour on selfing and the behaviour of normal plants after compatible cross-pollination.

Crosses between these self-compatible plants and test plants of known S genotypes revealed two different groups (table 7). Group I plants as females inhibited all the pollen of the original plant $\mathbf{S}_{3.6}$, while the other group inhibited only half of the pollen of the same plant. In four crosses with $\mathbf{S}_{2.3}$ and $\mathbf{S}_{2.6}$ plants the two groups behave differently.

There is only one interpretation of these results, viz. that in the irradiated $\mathbf{S}_{3} .6$ plant an $\mathbf{S} 6$ allele mutated to what may be symbolised as $\mathbf{S}^{\prime}$. When pollen carrying $\mathbf{S 6}^{\prime}$ was put on an $\mathbf{S}_{3} .6$ plant half the progeny was $\mathbf{S}_{3.6^{\prime}}$ and half $\mathbf{S} 6.6^{\prime}$; these are the two groups I and II respectively. 
All the group II plants were intercrossed in $5^{6}$ different combinations and in all cases, as expected, half the pollen was compatible and half incompatible.

\section{TABLE 7}

Incompatibility reactions of Oenothera plants with the mutant allele $\mathbf{S} 6^{\prime}$ as follows : + + , all pollen compatible; +-, compatible and incompatible pollen in a $I: I$ ratio; - -, all pollen incompatible

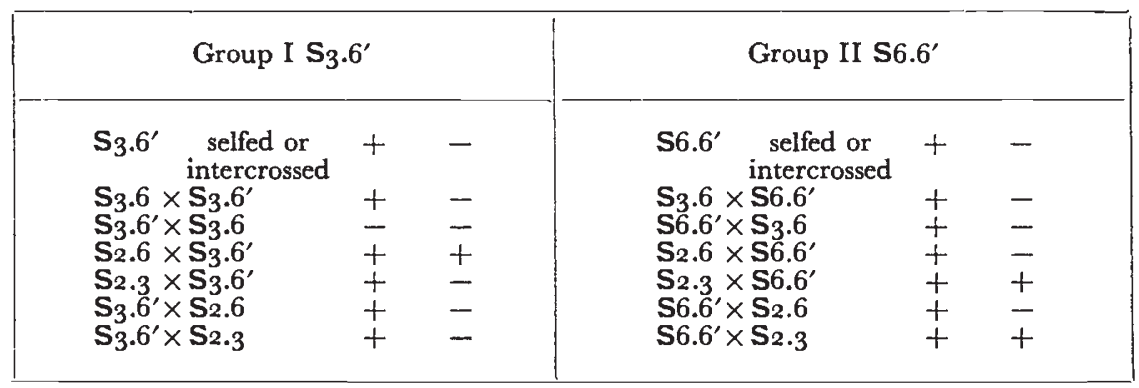

It will be seen from table 7 that a novel feature of this mutant allele $\left(\mathbf{S} 6^{\prime}\right)$ is that, despite its complete lack of action in the pollen grain, it operates fully in the style to inhibit $\mathbf{S} 6$ pollen (fig. 3).

\section{MUTATION

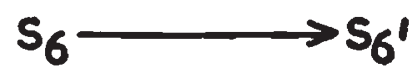 \\ OPERATION OF $\mathrm{S}_{6}^{\prime}$}

STYLE

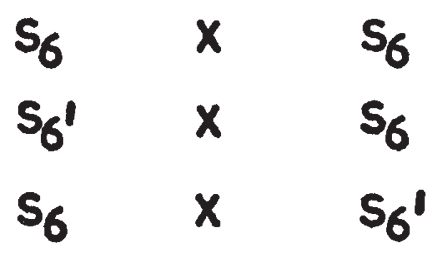

POLLEN

S6

S6

$\mathbf{S}^{\prime}$
RESULT

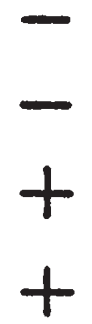

Fig. 3.-The operation of an X-ray induced mutant allele, S6'.

Progeny raised from a plant from each self-compatible group were tested with the relevant test plants and each segregated into two classes. The group I plants $\left(\mathbf{S}_{3} .6^{\prime}\right)$ produced $\mathbf{S}_{3} .6^{\prime}$ and $\mathbf{S} 6.6^{\prime}$ in approximately 
equal numbers. The group II (S6.6') plant produced $\mathbf{S 6 . 6 ^ { \prime }}$ and $\mathbf{S} 6^{\prime} .6^{\prime}$ plants; both results confirm the nature of the mutant allele.

On testing the $\mathbf{S} 6^{\prime} .6^{\prime}$ plants further it was found that when used as females they were fully incompatible with $\mathbf{S 6}$ pollen. Thus the $\mathbf{S} 6^{\prime}$ allele is fully operative in repelling $\mathbf{S} 6$ pollen even when not accompanied by a normal allele such as $\mathbf{S} 6$ or $\mathbf{S}_{3}$.

More detailed tests were made to find if the $\mathbf{S} 6^{\prime}$ allele had any other effect, a deleterious effect for example which is often associated with a minute deficiency. The results were as follows :-

(i) Both the pollen-germination and pollen-tube growth of $\mathbf{S} 6^{\prime}$ were equal to those of compatible pollinations with pollen carrying normal alleles.

(ii) In a cross-pollination between $\mathrm{S}_{2.4} \times \mathrm{S}_{3} .6^{\prime}$, that is, when $\mathrm{S}^{\prime}{ }^{\prime}$ pollen competes on equal terms with $\mathbf{S}_{3}$, the progeny segregated into 7 self-incompatibles and 7 self-compatibles, showing that $\mathbf{S} 6^{\prime}$ pollen is at no serious disadvantage when compared with $\mathbf{S}_{3}$.

(iii) Plants carrying one or two $\mathbf{S} 6^{\prime}$ alleles were in no way less vigorous than those with normal alleles.

(iv) Styles which were $\mathbf{S}_{3} \cdot 6^{\prime}$ inhibited $\mathbf{S} 6$ pollen just as strongly as $\mathbf{S} .6$ styles.

All these tests show therefore that the mutation has had no effect other than that of failing to produce the incompatibility reaction in the pollen grain.

It should be stated, however, that the selfed progeny of an $\mathbf{S}_{3} .6^{\prime}$ plant segregated into $23 \mathrm{~S}_{3} \cdot 6^{\prime}$ and I $_{4} \mathbf{S} 6^{\prime} .6^{\prime}\left(\chi^{2}=2 \cdot 18, p=\cdot_{15}\right)$ and although this deviation from expectation is not significant it

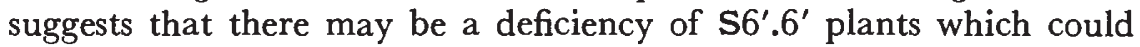
be due to embryos of lower viability.

In 1946 an induced mutation from X-ray treatment on an S2.6 plant and in 1947 six induced mutations from an $\mathbf{S}_{3} .6$ plant were of the same type-S6 $\rightarrow \mathbf{S} 6^{\prime}$.

However, another type of mutation was also found. Families of seedlings from six mutations from $\mathbf{S}_{3} .6$ plants were tested and the progeny of each segregated into two classes, $\mathbf{S}_{3} .6$ and $\mathbf{S 6 . 6}$ plants. Neither class was fully self-compatible but each set a few seeds at the end of the flowering season. In these cases it is probable that the S6 allele had mutated to give a weaker allele which did not operate efficiently at the end of the season. This view is supported by the fact that in other self-incompatible species such as Nicotiana sandere, endseason compatibility is known. The low temperature prevailing at this season also contributes to weakening the incompatibility reaction.

It is of interest that these mutants arose after pollinations made on end-of-season plants grown out-of-doors. In other words the rigorous selective mechanism of incompatibility was relaxed allowing small 
mutations that have only a slight effect on incompatibility to get through and produce seeds. Hence the kind of mutants found will depend largely on the selective mechanism operating.

\section{(f) Tests for crossing-over within the $\mathbf{S}$ gene}

The previous results have shown that the $S$ gene behaves towards $\mathrm{X}$-rays as if it were of two parts, one part operating only in the pollen and the other in the style and possibly in the pollen also. It seemed desirable, therefore, to test for crossing-over between the two parts. But before such tests could be planned it was necessary to define clearly the activity of the parts. We know that the $\mathbf{S} 6^{\prime}$ allele (the $\mathrm{X}$-ray mutant which is inactive in the pollen) is fully active in its original reaction in the style. This means that the stylar part of the $\mathbf{S}$ gene is specifically different for each allele. We do not know, however, if the pollen-active part is specific for each allele, or if it is non-specific and common to all alleles, merely extending to the pollen grain the activity of the stylar part.

If it is non-specific then crossing-over between say $\mathbf{S}_{3}$ and $\mathbf{S} 6^{\prime}$ would give $\mathbf{S}_{3}{ }^{\prime}$ and $\mathbf{S} 6$, which would restore the mutant $\mathbf{S} 6^{\prime}$ allele to its original state before mutation. If, on the other hand, the pollen part is specific then crossing-over will produce an entirely new allele, $\mathbf{S} 6^{3}$ which will have an $\mathbf{S} 6$ reaction in the style and $\mathbf{S}_{3}$ in the pollen. The first test was based on the assumption that the pollen active part is non-specific :-

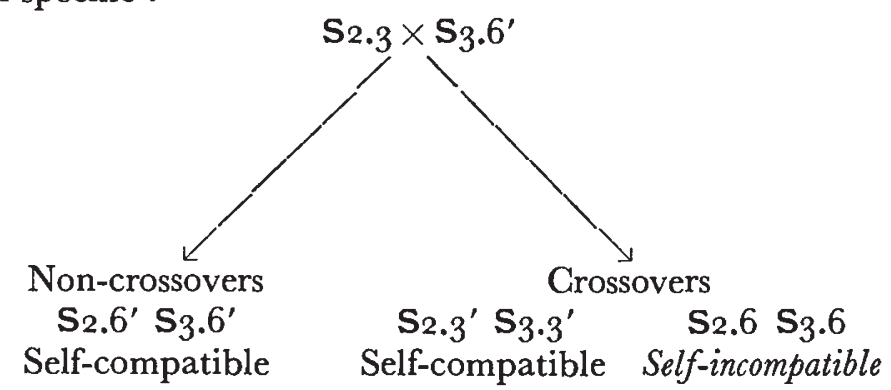

Thus any self-incompatible plants would be the result of crossingover within the $\mathbf{S}$ gene. From I49 plants tested none were found.

The second test was based on the assumption that the pollen-active part is specific. To make this test clear we must represent a normal allele as $\mathbf{S}^{3}, 3$ referring to the stylar reaction and ${ }^{3}$ to the pollen reaction, because both are specific to the particular allele. If $\mathbf{S 6}^{\prime}$ crosses over with $\mathbf{S}^{3}$ then an $\mathbf{S 6}^{3}$ allele would be produced which would have a 6 reaction in the style and a ${ }^{3}$ reaction in the pollen. The test cross is then :-

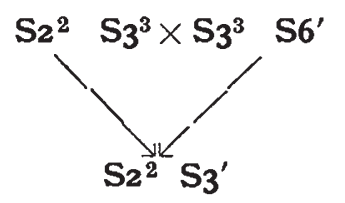

crossover

(Exceptional plant from crossing-over) 
The exceptional plant should be self-compatible, and incompatible as a female to $\mathbf{S 2}^{2} \mathbf{S}^{3}$ plants. None of these were found: crossingover had not occurred.

If the two parts are both specific, when crossing-over occurs between two normal alleles, e.g. $\mathrm{S}^{3}$ and $\mathrm{S}^{6}$, a plant carrying such a composite allele, $\mathrm{S}^{6}{ }^{6}$ or $\mathbf{S 6}^{3}$ would be self-compatible. Out of large numbers grown both at Merton and by Sterling Emerson in Pasadena, no self-compatible plants have been found except as a result of X-radiation. Crossing-over except as an extreme rarity can therefore be excluded.

\section{DISCUSSION}

(a) Nature of $\mathbf{S}$ gene mutants : temperature effect

None of the mutations of the $\mathrm{S}$ gene induced by X-rays have any measurable effect, even when homozygous, on the viability and fertility of the diploid plant, or on the haploid male or female gametophytes. This contrasts sharply with the results obtained by Stadler (194I) who found, with endosperm genes in maize, that all the X-ray induced mutants had very marked subsidiary effects on viability and fertility. He interpreted this as due to the visible endosperm mutations being associated with minute chromosomal deficiencies.

The explanation of the difference between the two results lies in the different selection that follows the X-ray treatment in the two cases.

The $\mathbf{S}$ gene mutants, from irradiations given at or before meiosis, have to be viable in the male haploid gametophyte before they can be detected. All haplo-lethals are therefore excluded. The maize mutants, on the other hand, are from treatments given to mature pollen, and since mutants produced at this stage are not likely to be expressed until after fertilisation, lethal mutations of all types will not be selected against.

This rigorous selection of the $\mathbf{S}$ mutants against lethality may have an important bearing upon a comparison with other gene mutation studies of effects such as temperature during irradiation.

Published accounts of the effects of temperature on the frequency of X-ray induced mutation in Drosophila are conflicting. TimoféeffRessovsky and Zimmer (1939) and Muller (1940) found no effect of temperature differences ranging from $3-37^{\circ} \mathrm{C}$. on sex-linked lethals induced by $1200-3000 r$ units. On the other hand King (1947) found the significant effect that the frequency of sex-linked lethals induced by doses ranging from 6oo-360o $r$ units was $2 \cdot 3$ times higher at $0^{\circ}$ than at $25^{\circ} \mathrm{C}$.

The positive effect of high temperature on increasing the number of induced viable $\mathbf{S}$ mutations in Prunus and Oenothera is apparently at variance with all these. However, if we assume a reduction by high temperature of the number of lethals mutations-associated probably with gross chromosomal changes-as found by King in Drosophila there would be a secondary effect of increasing the number 
of fully viable mutations because there would be less loss due to associated lethals.

The fact that the temperature effect on the $\mathrm{S}$ gene mutation does not operate when the chromosomes are fully condensed and charged with nucleic acid suggests that chromosome restitution is involved. If breaks that have restituted are less likely to be lethal than those which have not, then more restitution would lead to a higher viable $\mathbf{S}$ mutation under the selective conditions of the method. Since fully charged chromosomes are held together with nucleic acid and do not break it is to be expected that temperature under such conditions would have no effect. This would also explain the greater production of mutations when irradiation is at metaphase.

The whole problem of temperature and induced mutations, however, is not sufficiently known to be able to generalise and it is clear that much more work is necessary before a solution can be found.

\section{(b) Divisibility of the gene}

The $\mathbf{S}$ gene has been shown by the present experiments to consist of at least two parts, one part active in the pollen and the other in the style. Before this was known it had been shown, by examining the effect of this gene in diploid pollen of induced tetraploids that the different $\mathbf{S}$ alleles, while they do not interact in the style, show dominance and competition in the pollen (Lewis, 1947). This differential property as regards interaction in different tissues corroborates the theory that this gene is made up of 2 units.

The double structure of the $\mathbf{S}$ gene raises the general question of the constitution of the gene, but as this has been considered in detail by Raffel and Muller (I940) as a result of work on the Scute gene in Drosophila it will not be discussed except in so far as the present and recent published results extend it.

For a full discussion of the possible nature of multiple alleles, that is, whether they are variants of a single unit or rearrangements among a number of linked units, see Silow and Yu (I942).

For mutation to occur in one part of the $\mathbf{S}$ gene, without in any way affecting the other part, is exactly similar to the spontaneous independent mutation of the two parts of the $\mathbf{R}$ gene in maize (Stadler, I946). Thus, we are led to the inescapable conclusion that these genes are composite structures of parts which can reproduce without the presence of the other and hence the parts have the essential properties of genes. We have therefore the picture of a gene as a mechanical and functional unit which is equal to two mutational units. These units are held together in such a way at meiosis that no crossing-over takes place between them.

One of the most easily detected suppressors of crossing-over is a small inversion, and this could account for the absence of crossing-over between the units of two alleles, for example within the two composite incompatibility alleles in heterostyled plants (Ernst, 1936). In Primula 
there are two normal alleles each made up of three units, one controls anther height, one style length, one pollen size and incompatibility. But an inversion cannot prevent crossing-over between every possible pair of the hundreds of different incompatibility alleles that are present in homomorphic species such as Oenothera organensis.

\section{SUMMARY}

I. X-radiation was applied to Prunus avium and Oenothera organensis, when the pollen mother cells were in meiosis or at earlier stages. It increased the number of seeds or of compatible pollen tubes produced, according to the technique-after incompatible pollination. This was due to induced mutation of the incompatibility (S) gene. Treatments given to mature pollen had no immediate effect because the incompatibility reaction in the pollen had already been laid down.

2. High temperature at the time of irradiation when the treatments were given to nuclei in early prophase of meiosis increased the number of $\mathbf{S}$ mutations, but had no effect on nuclei treated in metaphase.

3. Treatments given at first metaphase produced 2-3 times as many mutants as the same treatment given at early prophase.

4. Groups of two compatible pollen tubes arising from one anther in Oenothera were the result of a mutation in an $\mathbf{S}$ gene which had one division to make before reaching the young pollen-grain stage. These double mutants appear in treatments that were given 5 days before metaphase I, but not in later treatments. This showed that the $\mathbf{S}$ gene divides mutationally long before pachytene when the chromosomes split.

5. Out of fourteen different X-ray mutants in Oenothera, eight of these $\left(\mathbf{S 6} \rightarrow \mathbf{S} 6^{\prime}\right.$ ) gave complete self-compatibility to the plant by the failure of the $\mathbf{S} 6^{\prime}$ allele to operate in the pollen; in the style, however, the mutant allele was fully operative in its original way (S6). The other six mutants were only partially self-compatible at the end of the flowering season. These partial mutants, which may be the result of smaller gene disturbances, were obtained by the use of a less rigorous selective mechanism.

6. None of the induced mutant alleles had any effect, even when homozygous on the vigour or fertility of the plant or of the male or female gametophytes.

7. The $\mathbf{S}$ gene is shown to be of at least two parts, one operating in the pollen and the other in the style, between which crossing-over is excluded.

\section{REFERENCES}

CRANE, M. B., AND BROWN, A. G. 1937.

Incompatibility and sterility in the sweet cherry, Prunus avium L.

7. Pomol., 15, 86- I 16.

DARLINGTON, C. D., AND LA COUR, L. F. 1945.

Chromosome breakage and the nucleic acid cycle.

7. Genet., 46, I80-267. 
ERNST, A. 1936 .

Heterostylie-Forschung. Versuche zur genetischen Analyse eines Organisationsund Anpassungs merkmales.

Z.I.A.V., 7I, $156-230$.

KING, E. D. 1947 .

The efiect of low temperature upon the frequency of $\mathrm{X}$-ray induced mutations.

Genetics, 32, I6 I-164.

LEWIS, D. $\quad$ I 947 .

Competition and dominance of incompatibility alleles in diploid pollen.

Heredity, I, 85-108.

LEWIS, D. I 948 .

Mutation of the incompatibility gene. I. Spontaneous mutation rate.

Heredity, 2, 219-236.

MULLER, H. J. 1940.

An analysis of the process of structural change in chromosomes of Drosophila.

7. Genet., 40, I-66.

NEWCOMBE, H. B. 1942.

The action of X-rays on the cell. I. The chromosome variable.

7. Genet., 43, 145-1 7 1.

PODDUBNAJA-ARNOLDI, v. 1936 .

Germination of pollen on artificial medium.

Planta, 25, 502.

RAFFEL, D., AND MULLER, H. J. 1940.

Position effect and gene divisibility considered in connection with three strikingly similar acute mutations.

Genetics, 25, 541-583.

SILOW, R. A., AND YU, G. P. 1942.

Anthocyanin patterns in Asiatic cottons.

J. Genet., 43, 249-284.

STADLER, L. J. 1930.

Some genetic effects of X-rays in plants.

7. Hered., 2I, 2-1 9 .

STADLER, L. J. I $94 \mathrm{I}$.

The comparison of ultraviolet and X-ray effects on mutation.

Cold. Spr. Harb. Symp., 9, 168-1 77 .

STADLER, L. J. $\quad$ I 946.

Spontaneous mutation of the $\mathrm{R}$ locus in maize. I. The aleurone color and plantcolor effects.

Genetics, 3I, 377-394.

TIMOFEEFF RESSOVSKY, N. W., AND ZIMMER, K. G. 1939.

Radiation genetics.

Strahlentherapie, 66, 684. 